\section{Wahyudi Barmawi}

Magister Ilmu Pemerintahan Universi-

tas Muhammadiyah Yogyakarta

Email: yudibarmawi@ymail.com

\section{Suranto}

Dosen Magister IImu Pemerintahan Universitas Muhammadiyah Yogyakarta

Email: suranto_umy@yahoo.com

http://dx.doi.org/10.18196/

igpp.2016.0055

\section{Analisis Implementasi Kebijakan Wajib Belajar 9 Tahun dalam Meningkatkan Mutu Pendidikan di Kota Ternate}

ABSTRACK

Education is very effective to build nation and country with dynamic civilization. Government Regulation number 47 of 2008 on compulsory education is intended to realize acceleration and even distribution of education to all direction with central and local government commitment. This research discusses implementation of 9 year compulsory education policy in Ternate and factors affecting the implementation. The research was intended (1) to identify implementation of 9 year compulsory education policy in improving educational quality in state primary school and state junior high school in Ternate and (2) to identify factors affecting implementation of 9 year compulsory education policy in improving educational quality in state primary school and state junior high school in Ternate. Theory used in this research is policy implementation refereeing to Grindle and Edward III views. This research used descriptive qualitative approach. The results show that implementation of compulsory education program in Ternate has not been optimal yet. It is indicated with attitude of policy executor in education office of Ternate in responding problems occurring in schools. There are many non-permanent employees in some school, one building for two school and library in SMPN 12 in Moti Island that was hit by abrasion have not been fixed. Conclusion of the research indicated that implementation of compulsory education program in Ternate has not been optimal yet. Factor affecting compulsory education policy is disposition. The disposition factor determines 9 year compulsory education policy in Ternate.

Keywords: policy implementation, compulsory education policy, education quality

ABSTRAK

Pendidikan merupakan sarana yang sangat efektif guna membangun bangsa dan Negara yang berperadaban dinamis. Adanya PP 47 tahun 2008 tentang wajib belajar dimaksudkan agar percepatan dan pemerataan pendidikan kesegala arah dapat diwujudkan dengan komitmen pemerintah dan pemerintah daerah. Penelitian ini membahas implementasi kebijakan wajib belajar 9 tahun di Kota Ternate dan faktor-faktor yang mempengaruhi implementasi tersebut. Tujuan penelitian ini adalah untuk: (1) untuk mengetahui implementasi kebijakan wajib belajar 9 tahun dalam meningkatkan mutu pendidikan pada Sekolah Dasar Negeri dan Sekolah Menengah Pertama Negeri di Kota Ternate, (2) untuk mengetahui faktorfaktor yang mempengaruhi implementasi kebijakan wajib belajar 9 tahun dalam meningkatkan mutu pendidikan pada Sekolah Dasar Negeri dan Sekolah Menengah Pertama Negeri di Kota Ternate. Sementara itu, teori yang dipergunakan yaitu implementasi kebijakan yang merujuk kepada pandangan Grindle dan Edward III. Penelitian ini menggunakan pendekatan deskriptif kualitatif. Hasil penelitian menunjukkan bahwa, pelaksanaan program wajib belajar di Kota Ternate belum optimal. Hal ini ditunjukkan dengan sikap pelaksana kebijakan di Dinas Pendidikan Nasional Kota Ternate dalam merespon permasalahan yang terjadi di sekolah. Masih banyaknya tenaga honorer dibeberapa sekolah, 1 bangunan sekolah dipergunakan 2 sekolah secara bergantian, dan bangunan perpustakaan yang berada di SMPN 12 Pulau Moti belum diperbaiki karena terkena abrasi. Kesimpulan dari penelitian ini menunjukkan implementasi kebijakan wajib belajar di Kota Ternate belum optimal. Faktor-faktor yang mempengaruhi kebijakan wajib 
belajar adalah faktor disposisi. Faktor disposisi yang paling menentukan kebijakan wajib belajar 9 tahun di Kota Ternate.

Kata kunci: Implementasi Kebijakan, Kebijakan Wajib Belajar, Mutu Pendidikan

\section{PENDAHULUAN}

Pendidikan merupakan sarana yang sangat efektif guna membangun bangsa dan Negara yang berperadaban dinamis. Oleh karenanya, sebagai pelaksana cita-cita untuk mencapai gagasan yang mulia tersebut tugas dan kewajiban Negara sebagai organisasi untuk memayungi, serta mempunyai tugas untuk berperan aktif dalam meningkatkan mutu pendidikan. Tercapainya tingkat pemerataan pendidikan ke segala arah tidaklah mudah terutama Negara Kesatuan Republik Indonesia (NKRI) yang merupakan negara kepulauan dengan garis pantai terpanjang di dunia. Banyak faktor penghambat di dalamnya, antara lain rentang kendali antar satu wilayah dengan wilayah yang lain, faktor ekonomi masyarakat yang disebabkan oleh kemiskinan, kebijakan pemerintah yang sentralistik, korupsi dan seterusnya. Ilyas (2013:1331) menyatakan bahwa "Pendidikan adalah sektor wilayah yang terpenting dari sebuah input pembangunan secara umum, karena merupakan fondasi dasar fundamental yang utama dalam suatu paradigma pembangunan, bahkan pendidikan menjadi domain utama bagi setiap negara yang ingin maju dan ingin menguasai teknologi”. Dalam rangka mewujudkan suatu cita-cita pendidikan nasional, sampai saat ini pemerintah Indonesia masih dihadapkan pada berbagai banyaknya kompleksitas permasalahan, baik permasalahan yang bersifat internal dan eksternal seperti kualitas pendidik yang belum memenuhi standar mutu, sarana, dan prasarana sekolah yang masih kurang memadai serta terbatasnya anggaran pendidikan yang disediakan oleh pemerintah. Selain faktor internal tantangan yang paling berat bagi bangsa Indonesia pada era globalisasi abad ke 21 ini adalah bagaimana menyiapkan sumber daya manusia yang cerdas, unggul, dan berdaya saing. United $\mathrm{Na}-$ tions (2011) dalam Nurdayana, dkk (2012:3) menyatakan bahwa 
"Pendidikan merupakan modal dasar pembangunan manusia. Mengingat pentingnya pendidikan bagi manusia, PBB menuangkannya dalam 8 tujuan pembangunan milenium pada butir ke 2 yaitu mencapai pendidikan dasar universal”. Sementara itu Diknas (2001) dalam Dwiningrum (2011:12-13) menambahkan bahwa: ada 3 permasalahan mendasar pendidikan yang ada di Indonesia khususnya pada pendidikan dasar dan menengah. Pertama kebijakan penyelenggaraan pendidikan nasional menggunakan pendekatan education fungtion atau input-output analisis yang tidak dilaksanakan secara konsekuen. Kedua, penyelenggaraan pendidikan nasional dilakukan secara birokratik sentalistik, sehingga menempatkan penyelenggara pendidikan sangat bergantung pada keputusan birokratis yang panjang dan keputusan yang dikeluarkan tidak sesuai dengan kondisi. Ketiga, peran masyarakat, dalam hal ini orang tua siswa dalam penyelenggaraan pendidikan. Hal ini didasarkan kepada dukungan dana, bukan kepada proses pendidikan (pengambil keputusan), pengawasan, evaluasi, dan akuntabilitas.

Kebijakan bidang pendidikan merupakan salah satu dari wilayah kekuasaan negara. Mengikuti konsep keadilan distributif John Rawls (1999) dalam (Budiraharjo, dkk, 2013: 5)., pemerintah sudah semestinya memainkan peran-peran yang adil dalam mendistribusikan sumber daya dan sumber dana bagi seluruh warga negaranya. Oleh karena itu, konsep keadilan tidak semata-mata menjadi jargon di dalam pendidikan. Tetapi menjadi lebih bermakna pada tataran implementasi. Sebagai suatu proses, pendidikan dimaknai sebagai semua tindakan yang mempunyai efek pada perubahan watak, kepribadian, pemikiran, keterampilan, dan prilaku. Dengan demikian, pendidikan bukan sekedar pengertian dalam arti kegiatan mentransfer ilmu, teori, dan fakta-fakta akademik semata, atau bukan semata urusan ujian, penetapan kriteria kelulusan, serta pencetakan ijazah semata akan tetapi pendidikan pada hakikatnya merupakan proses pembebasan peserta didik dari ketidaktahuan, 
ketidakmampuan, ketidakberdayaan, ketidakbenaran, ketidakjujuran, dan buruknya hati, ahlak, dan keimanan (Malik, 2013:3-4). Sebagai salah pusat informasi di Maluku Utara, Kota Ternate mempunyai daya magnet tersendiri antara lain sebagai pusat perdagangan, kebudayaan, dan pendidikan. Artinya bahwa, Kota Ternate telah menjadi sebuah miniatur labolatorium di provinsi Maluku Utara. Sehingga perlu pengembangan yang pada dasarnya meningkatkan derajat perubahan pada aspek sumber daya manusia yang mumpuni. Peran tersebut tentunya perlu keterlibatan pemerintah daerah dalam merancang dan memantapkan aspek yang belum maksimal.

Permasalahannya yaitu kekurangan tenaga pendidik, infrastruktur, dan akses transportasi menjadi problematika di beberapa kecamatan. Walikota Ternate dalam Musyawarah Perencanaan Pembangunan (Musrenbang) tingkat kecamatan Kota Ternate 2013, meminta beberapa kecamatan untuk menyampaikan permasalahan yang terjadi. Di kesempatan tersebut camat Pulau Ternate memaparkan persoalan-persoalan yang terkait dengan pelayanan dasar yang meliputi bidang kesehatan, sarana prasarana yang memerlukan peningkatan, dan pendidikan. Untuk bidang pendidikan sendiri sudah memadai namun masih dibutuhkan tenaga pendidik (http:/ / malutpost.com). Selain kekurangan tenaga pendidik, kondisi bangunan sebagai sarana penunjang juga menjadi krusial menyangkut dengan kegiatan belajar mengajar dan keamanan setiap siswa. Sumber yang di dapat pada koran lokal menyebutkan gedung laboratorium SMP Negeri 12 yang berada di kecamatan Moti terancam abrasi. Kondisi ini sudah terjadi pada tahun 2009 dan baru diketahui oleh anggota DPRD Kota Ternate 2014.

Laporan hasil Ujian Nasional (UN) tingkat Sekolah Menengah Pertama (SMP) yang dikeluarkan oleh Kementrian Pendidikan dan Kebudayaan Republik Indonesia, provinsi Maluku Utara tahun 2012 berada pada posisi 18 terbawah. Pada tahun 2013 mengalami 
peningkatan yang baik dengan menduduki 3 teratas. Tahun 2014 provinsi Maluku Utara masuk pada posisi 9. Hasil ujian nasional menunjukkan dari 3 tahun tersebut fluktuasi karena berbagai permasalahan. Terkait dengan pergantian kurikulum, sumber daya manusia, dan sarana prasarana. Sementara itu, dari 7 kabupaten dan 2 kotamadya yang berada di provinsi Maluku Utara. Hasil Ujian Nasional (UN) tahun 2014 untuk tingkat SMP, Kota Ternate menduduki posisi terbawah. Hal ini disampaikan oleh kepala seksi SMP Dinas Pendidikan Nasional Kota Ternate saat diwawancarai. Alasannya adalah penilaian yang begitu ketat sehingga ada penurunan hasil Ujian Nasional. Merujuk pada Laporan Akuntabilitas Kinerja Instansi Pemerintah (Lakip) tahun 2013 di mana Angka Partisipasi Kasar, Angka Partisipasi Murni meningkat. Dari target Angka Partisipasi Kasar untuk Sekolah Dasar 100,50 \% dan Angka Partisipasi Murni 95,50 \%, Dinas Pendidikan Nasional Kota Ternate mampu merealisasikan 105,79\%. Sementara untuk Sekolah Menengah Pertama Angka Partisispasi Kasar yang ditargetkan 90,50 \% menjadi 99, 79 \&. Sementara Angka Partisipasi Murni dari 95,50\%, hanya dapat direalisasikan 86,91\%.

\section{KERANGKA TEORI}

\section{KEBIJAKAN PUBLIK}

Menurut pemahaman Harold Laswell dan Abraham Kaplan dalam Tilaar dan Nugroho, (2012: 183) kebijakan publik didefinisikan sebagai sesuatu program yang diproyeksikan dengan tujuan-tujuan tertentu nilai-nilai tertentu, dan praktek-praktek tertentu (a projected program of goals, values, and practices). Sementara itu, Thomas R. Dye (1978) menyatakan kebijakan publik ialah pilihan tindakan apa pun yang dilakukan atau tidak dilakukan oleh pemerintah. Selain pendapat Dye, pakar Inggris W. I. Jenkis merumuskan kebijakan publik sebagai serangkaian keputusan yang saling berkaitan yang diambil seorang aktor politik atau sekelompok 
aktor, berkenaan dengan tujuan yang telah dipilih beserta cara-cara untuk mencapainya dalam suatu situasi. Keputusan-keputusan itu pada prinsipnya masih dalam batas-batas kewenangan kekuasaan para aktor tersebut (Abdul Wahab, 2014: 14-15).

\section{IMPLEMENTASI KEBIJAKAN}

Implementasi kebijakan yang menjadi fokus dari bahasan dalam penelitian ini mengenai implementasi kebijakan wajib belajar 9 tahun. Untuk itu diperlukan landasan teori sebagai pedoman penelitian ini mengenai implementasi kebijakan terkait dengan penelitian ini. Implementasi kebijakan merupakan aktifitas yang paling penting. Menurut Udoji dalam Abdul Wahab (2014:126), pelaksanaan kebijakan adalah sesuatu hal penting bahkan mungkin jauh lebih penting dari pada pembuatan kebijakan. Kebijakankebijakan akan berupa impian atau rencana bagus yang tersimpan rapi dalam arsip kalau tidak terimplementasikan. Daniel A. Mazmanian dan Paul A. Sabatier (1979) dalam Abdul Wahab (2014: 135) menjelaskan makna implementasi ini dengan menyatakan bahwa, memahami apa yang senyatanya terjadi sesudah suatu program dinyatakan berlaku atau dirumuskan merupakan fokus perhatian implementasi kebijakan, yakni kejadian-kejadian, dan kegiatan-kegiatan yang timbul sesudah disahkannya pedomanpedoman kebijakan publik yang mencakup baik usaha-usaha untuk mengadministrasikannya maupun untuk menimbulkan akibat/ dampak nyata pada masyarakat atau kejadian-kejadian. Menurut Suranto (2013: 21) secara umum, implementasi kebijakan dapat diartikan sebagai tindakan yang dilakukan oleh pemerintah dan swasta, baik secara individu atau kelompok dengan maksud untuk mencapai tujuan yang telah dirumuskan dalam kebijakan. Secara sederhana kegiatan implementasi kebijakan merupakan suatu kegiatan penjabaran rumusan kebijakan yang bersifat abstrak menjadi tindakan yang bersifat konkrit, atau dengan kata lain 
pelaksanaan (formulasi) kebijakan yang menyangkut aspek manejerial dan teknis proses implementasi akan dimulai setelah tujuantujuan dan sasaran-sasaran telah ditetapkan, program kegiatan telah disusun untuk mencapai sasaran tersebut. Sejatinya bahwa implementasi kebijakan merupakan faktor penting dalam mewujudkan ide-ide yang merupakan keluaran dari pembuat kebijakan. Grindle (1980) yang dikutip Suranto (2013:35) menyatakan bahwa proses umum implementasi dapat dimulai ketika tujuan dan sasaran telah dispesifikasi, program-program telah didesain, dan dana dialokasi untuk percepatan tujuan. Kegiatan hal tersebut merupakan syaratsyarat dasar (the content of policy) dan konteks kebijakan (the content of policy) yang terkait dengan formulasi kebijakan. Keberhasilan implementasi nenurut Grindle dipengaruhi oleh variabel besar, yakni isi kebijakan (content of policy) dan lingkungan implementasi (content of implementation). Adapun isi kebijakan mencakup hal-hal sebagai berikut:

1. Kepentingan yang terpengaruhi

2. Jenis manfaat yang akan dihasilkan

3. Derajat perubahan yang diinginkan

4. Kedudukan pembuat kebijakan

5. Siapa pelaksana program

6. Sumber daya yang dikerahkan

Sementara konteks kebijakan adalah menurut Grindle (1980):

1. Kekuasaan, kepentingan, dan strategi aktor yang terlibat

2. Karakteristik lembaga dan penguasa

3. Kepatuhan dan daya tanggap (Grindle dalam Suranto, 2013: 35).

Menurut pendapat Edward III dalam Nugroho (2012: 693), masalah utama administrasi publik adalah "lack of attention to implementation". Dikatakannya, "without effective implementation the decision of policymakers will not be carried out successfully". Edward III menyarankan untuk memperhatikan empat isu pokok agar implementasi kebijakan menjadi efektif, yaitu communication, 
resource, disposition or attitudes, dan bureaucratic structures. Komunikasi berkenaan dengan bagaimana kebijakan dikomunikasikan pada organisasi dan publik dan sikap serta tanggapan dari para pihak yang terlibat. Resources berkenaan dengan sumber daya pendukung, khususnya sumber daya manusia. Hal ini berkaitan dengan kecakapan pelaksana kebijakan publik untuk carry out kebijakan secara efektif. Disposition berkenaan dengan kesediaan dari pada implementator untuk carry out kebijakan publik tersebut. Kecakapan saja tidak mencukupi, tanpa kesediaan dan komitmen untuk melaksanakan kebijakan. Struktur birokrasi berkenaan dengan kesesuaian organisasi birokrasi yang menjadi penyelenggara implementasi kebijakan publik. Tantangannya adalah bagaimana agar tidak terjadi bureaucratic fragmentation karena struktur ini menjadikan proses implementasi menjadi jauh dari efektif (Tilaar dan Nugroho, 2012: 223). Menurut Edward III terdapat empat variabel utama terkait dengan implementasi dan dapat diukur dengan beberapa hal yakni:

1. Komunikasi
a. Transmisi
b. Kejelasan
c. Konsistensi

2. Sumberdaya
a. Staf
b. Informasi
c. Wewenang
d. Fasilitas

3. Disposisi
a. Pengangkatan Birokrat
b. Insentif

4. Struktur Organisasi
a. Standar Operating Prosedures (SOPs)
b. Fragmentasi 


\section{KEBIJAKAN WAJIB BELAJAR}

Kebijakan wajib belajar merupakan langkah pemerintah untuk memperbaiki kualitas manusia Indonesia berdasarkan amanah UUD 45. Wajib belajar merupakan program yang ditetapkan pemerintah Indonesia berdasarkan Peraturan Pemerintah nomor 47 Tahun 2008 Tentang Wajib Belajar. Sebagaimana yang diatur di dalam Undangundang nomor 20 tahun 2003 Tentang Sistem Pendidikan Nasional pasal 18 menjelaskan Wajib belajar adalah program pendidikan minimal yang harus diikuti oleh Warga Negara Indonesia atas tanggung jawab Pemerintah dan Pemerintah Daerah. Apabila kebijakan pendidikan ditekankan semata-mata untuk kepentingan sosial maka kebijakan pendidikan disubordinasikan pada kebijakan publik di Negara totaliter. Implikasi dari kebutuhan akan adanya harmoni antara kebijakan pendidikan dan kebijakan publik ialah masalah pendidikan bukan lagi monopoli suatu kelompok masyarakat, apalagi bagi kelompok masyarakat ekonomi kuat, tetapi merupakan persoalan seluruh masyarakat dan oleh sebab itu juga merupakan masalah politik dan masalah ekonomi dari suatu masyarakat dan bangsa (Tilaar dan Nugroho, 2012: 310)

\section{PENDIDIKAN DASAR}

Fungsi, tujuan, dan kewajiban pemerintah untuk mewujudkan pendidikan yang bermutu bagi bangsa Indonesia telah dilakukan oleh pemerintah dari waktu ke waktu. Rendahnya mutu pendidikan nasional, telah berpengaruh secara langsung maupun tidak langsung terhadap rendahnya mutu dan daya saing sumber daya manusia Indonesia pada bursa tenaga kerja global (Budiraharjo dkk, 2013: 40). Laporan Pencapaian Tujuan Pembangunan Milenium Di Indonesia 2011 Kementerian Perencanaan Pembangunan Nasional/ Badan Perencanaan Pembangunan Nasional (2011: 13) untuk mempercepat pencapaian sasaran MDGs, Presiden telah menetapkan Instruksi Presiden nomor 3 Tahun 2010 Tentang Pro- 
gram Pembangunan yang Berkeadilan. Salah satu amanat yang tercantum dalam Inpres tersebut adalah agar setiap Kementerian/ Lembaga, Gubernur, dan Para Bupati/Walikota mengambil langkahlangkah yang diperlukan sesuai tugas, fungsi, dan kewenangan masing-masing dalam rangka pelaksanaan program-program pembangunan yang berkeadilan, antara lain meliputi program pencapaian Tujuan Pembangunan Milenium (Millenium Development Goals- MDGs).

Barnadib (2002: 5) mengemukakan bahwa pendidikan sebagai pengetahuan atau ilmu mempunyai bagian yang terdiri dari atas dasar dan fakta. Lazimnya dasar bersifat abstrak. Pendidikan di Indonesia yang dimaksud adalah nilai-nilai dan norma-norma yang bersumber pada Pancasila, misalnya keadilan. Keadilan sebagai nilai bersifat abstrak dan baru akan menjadi konkrit bila diterapkan dalam bidang tertentu, seperti bidang hukum.

\section{METODOLOGI PENELITIAN}

Jenis penelitian yang akan digunakan yaitu pendekatan deskriptif kualitatif. Sugiyono (2014: 378) menyatakan bahwa pada penelitian kualitatif, penentuan fokus berdasarkan hasil studi pendahuluan, pengalaman, referensi, dan disarankan oleh pembimbing atau orang yang dipandang ahli. Fokus dalam penelitian ini masih bersifat sementara dan akan berkembang setelah peneliti dilapangan. Menurut Maleong (2014: 6) Penelitian kualitatif adalah penelitian yang menghasilkan prosedur analisis yang tidak menggunakan prosedur analisis statistik atau cara kuantifikasi lainnya. Sementara Bogdan dan Biklen (1992) yang dikutip oleh Rahmat (2009) menjelaskan bahwa penelitian kualitatif adalah salah satu prosedur penelitian yang menghasilkan data deskriptif berupa ucapan atau tulisan, dan prilaku orang-orang yang diamati. Pendekatan kualitatif diharapkan mampu menghasilkan uraian yang mendalam tentang ucapan, tulisan, dan atau perilaku yang dapat diamati dari suatu 
individu, kelompok, masyarakat, dan atau organisasi tertentu yang dikaji dari sudut pandang yang utuh komperhensif, dan holistik.

Lokasi penelitian berada di Kota Ternate Provinsi Maluku Utara. Ada beberapa alasan dan pertimbangan dalam menentukan lokasi penelitian ini antara lain sebagai berikut: 1) Kota Ternate merupakan salah satu gerbang pendidikan di provinsi Maluku Utara; 2) Sekolah Dasar Negeri dan Sekolah Menengah Pertama Negeri merupakan penyelenggara kebijakan wajib belajar 9 tahun.

Jenis data yang digunakan dalam penelitian ini adalah data primer dan sekunder.

\section{A. DATA PRIMER}

Data yang dipergunakan dalam penelitian ini didapatkan melalui observasi terhadap lokasi penelitian, wawancara mendalam dan dokumentasi yang berkaitan langsung penelitian. Adapun data primer yang dimaksud dalam penelitian ini adalah pendapat informan yang diwawancarai antara lain Dinas Pendidikan Kota Ternate, Kepala Sekolah Dasar Negeri Sekolah Menengah Pertama Negeri, dan Unit Pelayanan Teknis Dinas yang berkaitan dengan pelaksanaan kebijakan wajib belajar 9 tahun dalam meningkatkan mutu pendidikan Sekolah Dasar Negeri dan Sekolah Menengah Pertama Negeri di Kota Ternate.

\section{B. DATA SEKUNDER}

Data sekunder adalah data pendukung guna melengkapi data primer. Data sekunder di dapat dari buku-buku, jurnal, arsip, Peraturan Perundang-undangan, media massa, penelitian-penelitian terdahulu yang berkaitan dengan implementasi wajib belajar. Data sekunder dalam penelitian ini adalah: Gambaran umum wilayah Kota Ternate, Profil Dinas Pendidikan Kota Ternate. Profil Dinas Pendidikan ini dimaksudkan untuk mengetahui gambaran dan kinerja pelaksanaan terkait dengan program wajib belajar 9 tahun di Kota Ternate. Dilihat dari komunikasi antar lembaga, sumber 
daya manusia di Dinas Pendidikan, Disposisi dalam hal ini pengangkatan birokrat dan insentif, terakhir adalah struktur birokrasi di Dinas Pendidikan. Sehingga dapat mempermudah pengambilan data dengan adanya profil tersebut

Jumlah Sekolah Dasar Negeri dan Sekolah Menengah Pertama Negeri di Kota Ternate, Profil Sekolah Sekolah Dasar Negeri dan Sekolah Menengah Pertama Negeri, Tugas Pokok dan Fungsi Dinas Pendidikan Nasional Kota Ternate, Laporan bulanan Sekolah Dasar Negeri dan Sekolah Menengah Pertama Negeri di Kota Ternate Jumlah pegawai Dinas Pendidikan Kota Ternate dan Laporan Akuntabilitas Kinerja Instansi Pemerintah (Lakip)

Teknik pengumpulan data merupakan langkah yang paling utama dalam penelitian, karena tujuan utama dari penelitian adalah mendapatkan data. Tanpa mengetahui teknik pengumpulan data, maka peneliti tidak akan mendapatkan data yang memenuhi standar data yang ditetapkan (Sugiyono, 2014: 308). Pengumpulan data dilakukan dengan observasi, wawancara, dokumentasi. Dari tiga tahapan ini, penelitian ini meggunakan teknik wawancara dan dokumentasi.

\section{PEMBAHASAN}

\section{DATA HASIL PENELITIAN}

Data penelitian lapangan ini berguna untuk menjelaskan masalah yang terjadi. Hasil analisis data mempergunakan teori yang mana indikator atau alat ukur yang menjadi acuan untuk melihat implementasi kebijakan wajib belajar 9 tahun di Kota Ternate. sejauh mana isi kebijakan dan konteks kebijakan di pengaruhi oleh komunikasi, sumberdaya, disposisi, dan struktur birokrasi. Implementasi Kebijakan Bidang Pendidikan Dasar di Kota Ternate

Analisis dari penelitian ini melihat tanggapan dari informan terkait dengan implementasi kebijakan wajib belajar 9 tahun di Kota Ternate. Adapun isi dan konteks kebijakan yang akan dilihat sebagai faktor yang dipengaruhi. Pada isi dan konteks kebijakan di analisis 
mempergunakan penjabaran indikator dari data yang ditemukan dilapangan dapat dilihat dari isi kebijakan dan konteks kebijakan.

\section{HASIL ANALISIS DATA DIMENSI ISI KEBIJAKAN}

Dimensi dari isi kebijakan mempergunakan beberapa indikator sebagai berikut: 1 . Kepentingan yang terpengaruhi oleh kebijakan Kebijakan wajib belajar 9 tahun di Kota Ternate mempengaruhi beberapa kepentingan masyarakat sebagai wujud dari perubahan yang diinginkan dari kebijakan tersebut. Kepentingan yang terpengaruhi dari kebijakan tersebut terdapat pada peningkatan partisipasi siswa dan kemudahan akses pendidikan. Pada tahun 2009 Angka Partisipasi Kasar (APK) penduduk berusia 7-12 tahun (SD) sebesar 103,47 persen, untuk Angka Partisipasi Murni (APM) sebesar 92,94 persen dan Angka Putus Sekolah sebesar 0,12 persen. Sedangkan APK kelompok usia 13-15 tahun (SMP) adalah sebesar 102,36 persen, untuk Angka Partisipasi Murni (APM) sebesar 89,94 persen dan Angka Putus Sekolah sebesar 0,16 persen (Bappeda Kota Ternate, 2010: 20).

\section{KEBIJAKAN PEMBERIAN ANGGARAN PENDIDIKAN}

20 persen dari pemerintah pusat memberikan keuntungan bagi orang tua siswa. Khususnya yang tidak mampu dalam membiayai anak-anak mereka untuk bersekolah. Pemanfaatan anggaran pendidikan berguna bagi kualitas sumber daya manusia yang diinginkan. Dengan anggaran tersebut orang tua khususnya yang tidak mampu tidak perlu mengkhawatirkan biaya. Kemudahan akses untuk mendapatkan pendidikan dasar merupakan tanggungjawab pemerintah dan pemerintah daerah. Kemudahan tersebut dan tanggungjawab harus di ikuti dengan kesadaran terhadap pentingnya memajukan pendidikan yang bermutu pada setiap warga negara. Kemudahan akses pendidikan di Kota Ternate telah terjangkau oleh semua pihak. Tentunya hal ini tetap dipertahankan guna menambah 
antusias masyakat dalam percepatan pembangunan kedepannya. Akses pendidikan kepada setiap warga Negara tidak harus lagi mempertimbangkan kelas. Perubahan dunia yang semakin pesat, membutuhkan akses pendidikan yang merata dan berkualitas.

\section{JENIS MANFAAT YANG AKAN DIHASILKAN}

Manfaat yang akan dihasilkan dari sebuah kebijakan yakni wajib belajar 9 tahun meliputi peningkatan pendidikan yang berkualitas. Di mana aspek-aspek manfaat yang didapatkan setelah kebijakan tersebut dilaksanakan. Upaya pemerintah dalam menyelenggarakan pendidikan sebagaimana yang dimaksud dalam Uundang-undang Nomor 20 Tahun 2003 Tentang Sistem Pendidikan Nasional, pasal 3 menyebutkan Pendidikan nasional berfungsi mengembangkan kemampuan dan membentuk watak serta peradaban bangsa yang bermartabat dalam rangka mencerdaskan kehidupan bangsa, bertujuan untuk berkembangnya potensi peserta didik agar menjadi manusia yang beriman dan bertakwa kepada Tuhan Yang Maha Esa, berakhlak mulia, sehat, berilmu, cakap, kreatif, mandiri, dan menjadi warga negara yang demokratis serta bertanggung jawab. Kepedulian pihak pelaksana kebijakan terus berupaya agar wajib belajar 9 tahun di Kota Ternate dapat menyentuh kepada masyarakat yang kurang mampu. Manfaat dari kebijakan wajib belajar tersebut dapat dirasakan oleh siswa yang memperoleh pendidikan sebagaimana yang dijelaskan oleh PP 47 tahun 2008 tentang wajib belajar.

\section{DERAJAT PERUBAHAN YANG DIINGINKAN}

Perubahan yang diinginkan dari kebijakan wajib belajar 9 tahun yaitu pemerataan akses tingkat pendidikan dan tidak ada perbedaan perlakuan terhadap kelompok masyarakat tertentu. Adanya perubahan dari kebijakan tersebut dapat menciptakan ruang antara pelaksana kebijakan dan penerima kebijakan. Kemanfaatan yang diinginkan dari setiap orang berbeda-beda, hal ini perlu disandarkan 
pada Peraturan Pemerintah Nomor 47 Tahun 2008 Tentang Wajib Belajar. Sebagaimana yang tercantum di dalam ketentuan umum pasal 1 ayat 1 yang menyatakan wajib belajar adalah program pendidikan minimal yang harus diikuti oleh warga negara Indonesia atas tanggung jawab pemerintah dan pemerintah daerah. Derajat perubahan ini belum terlihat maksimal, dikarenakan permasalahan ini telah dilaporkan kepada Dinas Pendidikan Kota Ternate. Sikap pelaksana inilah yang menjadi permasalahan yang kurang responsif menanggapi permasalahan yang ada. Sehingga perlu pembenahan pada pelaksana kebijakan yang berada di bawah memberikan dapat bekerja dengan baik.

\section{KEDUDUKAN PEMBUAT KEBIJAKAN}

Dukungan pembuat kebijakan yaitu Dinas Pendidikan Nasional Kota Ternate merupakan instansi yang menyelenggarakan kebijakan wajib belajar 9 tahun. Peran Dinas Pendidikan Nasional Kota Ternate sebagai pembuat kebijakan terkait pendidikan dasar harus merujuk kepada program-program yang relevan dengan sekolah.

Kedudukan pembuat kebijakan yang berada di Kota Ternate, merupakan kunci dari keterlaksanaan dari Peraturan Pemerintah Nomor 47 Tahun 2008 Tentang Wajib Belajar. Sebagaimana yang telah dikemukakan oleh para informan, terkait peran Dinas Pendidikan Nasional Kota Ternate mempunyai andil dalam perencanaan pendidikan yang berada di Kota Ternate.

Terkait dengan program perencanaan yang dilakukan oleh Dinas Pendidikan Nasional Kota Ternate, ada beberapa hal yang menarik untuk dianalisis. Pertama, terkait dengan pelaksanaan hari-hari besar nasional dan daerah. Dimana Dinas Pendidikan Nasional Kota Ternate selalu melibatkan pihak sekolah untuk berpartisipasi. Hanya saja di dalam 13 item petunjuk teknis penggunaan dana Bantuan Operasional Sekolah (BOS) tidak diperuntukan untuk kegiatan semacam itu. Kedua, layanan internet yang tidak terjangkau di 
daerah oleh sinyal misalnya kecamatan Pulau Moti. Hal ini berakibat pengiriman laporan-laporan menjadi terhambat. Ketiga, persoalan aliran listrik yang menghampiri oleh kecamatan Pulau Moti dan kecamatan Bantang Dua. Kiranya ketiga poin ini harus diselesaikan sesegera mungkin.

\section{SUMBERDAYA YANG DIKERAHKAN}

Menjalankan roda organisasi yang baik perlu didukung dengan sumberdaya yang maksimal. Sumber daya tersebut meliputi sumber daya manusia, finansial, dan infrastruktur, sehingga organisasi dapat berjalan dengan sehat. Perlu pemantapan ditubuh organisasi agar tidak melenceng dari ketetapan yang ada. Banyak faktor yang akan menghambat jalannya sebuah kebijakan. Dari karakteristik masyarakat, budaya, ekonomi, politik, dan lain-lain. Sehingga memerlukan dukungan sumberdaya yang memadai akan membawa arah perubahan yang diinginkan serta kinerja yang ingin dicapai bersama. Dinas Pendidikan Nasional Kota Ternate dalam menjalankan pelaksanaan pendidikan dasar di wilayah Kota Ternate selama ini masih mengalami kendala. Terkait dengan sumber daya manusia dan sarana prasarana. Untuk itu perlu dikemukakan dari temuan yang ada dilapangan terkait dengan beberapa poin diatas dari hasil wawancara dan data yang ditemukan.

Penjelasan terkait sarana prasarana penunjang wajib belajar yang berada di Kota Ternate, pada dasarnya sarana prasarana pendukung perlu mendapat perhatian dari pemerintah. Kecermatan pihak-pihak terkait yang menjadikan pendidikan di Kota Ternate maju atau mundur. Tergantung dari sikap pelaksana kebijakan dalam memberikan kontribusinya bagi kegiatan pendidikan.

\section{HASIL ANALISIS DATA DIMENSI KONTEKS KEBIJAKAN}

Adapun hasil analisis dari konteks kebijakan meliputi berikut: (1) Kekuasaan, kepentingan, dan strategi aktor yang terlibat (2) 
karakteristik lembaga penguasa, dan (3) kepatuhan daya tanggap. Dari ketiga poin tersebut akan terlihat bagaimana konteks kebijakan dipengaruhi oleh dimensi lainnya. Kekuasaan, Kepentingan, dan Strategi Aktor Yang Terlibat Apakah kekuasaan itu? Pada suatu tingkat, konsep kekuasaan sangat sederhana, kekuasaan menunjuk pada kemampuan agen-agen sosial, perwakilan-perwakilan, dan institusi-institusi untuk mempertahankan dan mentransformasikan lingkungan mereka, sosial atau fisik, dan kekuasaan berkenaan dengan sumber-sumber yang menekankan kemampuan ini dan kekuatan-kekuatan yang membentuk dan mempengaruhi pelaksanaannya (Held, 2004: 209). Dari beberapa penjelasan informan maka dapat disimpulkan bahwa kekuasaan dan kepentingan para aktor selalu dibatasi dengan aturan yang ada. Sebagaimana yang diatur dalam Peraturan Walikota Nomor 33 Tahun 2010 Tentang Tugas Pokok dan Fungsi Dinas Pendidikan Kota Ternate. Perlu diketengahkan bagaimana bentuk pengawasan yang ada di Sekolah Dasar (SD), Taman Kanak-kanak (TK) dibawah pengawasan UPTD yang berada di setiap kecamatan. Sementara sekolah Menengah Pertama (SMP) pengawasannya berada langsung dibawah pengawasan Dinas Pendidikan Nasional Kota Ternate.

\section{KARAKTERISTIK LEMBAGA DAN PENGUASA}

Karakteristik lembaga yang menjalankan fungsi sebagaimana yang telah ditetapakan oleh mekanisme yang ada. Pembagian tugas antara pusat dan daerah mengindikasikan, adanya cara pandang yang memberikan daerah lebih kreatif dalam mengelola pemerintahan. Sebagai konsekuensinya, pemerintah daerah harus lebih cermat dalam melihat kelemahan daerah dari berbagai sisi. Data dari penelitian ini menunjukkan Analisis Beban Kerja (ABK) dan Tugas Pokok dan Fungsi (Tupoksi) dan Standard Operating Procedures (SOP) merupakan instrumen Dinas Pendidikan Nasional Kota Ternate dan UPTD. Sehingga lebih mempermudah pemahaman 
pelaksana kebijakan di Kota Ternate.

\section{KEPATUHAN DAN DAYA TANGGAP}

Kepatuhan dan daya tanggap kelompok yang menjadi sasaran kebijakan wajib belajar di Kota Ternate merupakan hal yang diinginkan. Tindaklanjut dari kebijakan menuntuk pelaksana kebijakan dalam hal ini sekolah dan UPTD yang berada di wilayah Kota Ternate di tuntut memberikan respon terhadap kebijakan tersebut. Sikap sebagai bentuk kepatuhan inilah yang menjadi landasan pelaksana kebijakan menjalanan amanat konstitusi. Proses pelaksanaan kebijakan wajib belajar dari waktu kewaktu cukup baik. Partisipasi masyarakat, berkurangnya angka putus sekolah, dukungan pemerintah daerah dalam hal pendidikan, dan pelaksana kebijakan yakni sekolah dan UPTD. Tingkat kepatuhan pelaksana kebijakan yang baik, perlu didorong dengan kepemimpinan yang memberikan memahami benar kebutuhan dilapangan. Kewenangan yang diberikan oleh Dinas Pendidikan Nasional Kota Ternate terhadap pelaksana kebijakan mencerminkan rasional agar tidak terkesan kaku dalam menjalankan sebuah kebijakan.

\section{HASIL ANALISIS DARI FAKTOR-FAKTOR YANG MEMPENGARUHI IMPLEMENTASI}

Kebijakan Pelaksanaan kebijakan wajib belajar yang tertuang di dalam PP 47 tahun 2008, yang pada dasarnya untuk memberikan kemudahan akses setiap warga negara memperoleh pendidikan dasar. Upaya yang dilakukan oleh pemerintah dengan diterbitkannya peraturan tersebut perlu mendapatkan apresiasi. Pada gilirannya akan membawa perubahan kepada cita-cita Pancasila sebagai bentuk idealnya. Berdasarkan teori yang dipergunakan untuk menganalisis faktor-faktor yang mempengaruhi implementasi kebijakan wajib belajar 9 tahun di Kota Ternate, terdapat beberapa indikator yang dapat diurai dengan penjelasan terkait dengan dimensi masing- 
masing. Ada pun penjelasan analisis dari indikator sebagai berikut:

\section{ANALISIS DATA DIMENSI KOMUNIKASI}

Upaya untuk mengetahui komunikasi yang dilakukan antara lembaga atau internal lembaga berjalan, komunikasi juga membantu agar proses kebijakan dapat berjalan sukses sesuai dengan harapan. Komunikasi yang baik dan intens akan berdampak kepada pemahaman pelaksanan organisasi. Komunikasi tidak hanya sebatas kepada individu dengan individu, akan tetapi seluruh pemangku kepentingan yang menjadi dari bagian kebijakan tersebut. Dukungan komunikasi yang dilakukan oleh Dinas Pendidikan Nasional Kota Ternate terhadap pelaksana tugas dilapangan diharapkan akan memberikan pemahaman sehingga ada pemerataan ditingkatan pelaksanan kebijakan. Dukungan komunikasi tersebut seperti sosialisasi, rapat, pelatihan kepada sekolah-sekolah untuk membantu penyampaian komunikasi.

Aspek kejelasan dalam pelaksanaan wajib belajar 9 tahun, memerlukan petunjuk pelaksanaan. Hal ini berkaitan dengan berjalannya kebijakan tersebut. Kejelasan pesan mengenai petunjukpetunjuk dari kebijakan yang akan ditindaklanjuti oleh pelaksana kebijakan yaitu sekolah dan UPTD, sehingga berdampak kepada hasil yang diinginkan baik atau tidaknya kebijakan.

Terkait dengan konsistensi atau kejelasan dari perintah kepada pelaksana kebijakan. Dinas Pendidikan Nasional Kota Ternate perlu menekankan kepada pelaksana kebijakan terkait dari kebijakan yang akan dijalankan. Hal ini menurut Edward dalam Suranto (2013: 42) bahwa dari beberapa faktor yang menghasilkan komunikasi yang tidak jelas juga menyebabkan komunikasi yang tidak konsisten. Aspek kejelasan dari informasi terkait dengan kebijakan wajib belajar 9 tahun sudah dijalankan oleh sekolah. Dari penilaian terhadap kejelasan informasi yang berada di sekolah telah terbangun untuk proses selanjutnya. Hal ini dikarenakan bentuk kesadaran pelaksana 
kebijakan akan tugas yang dijalankan kewajiban sebagai seorang pendidik.

\section{ANALISIS DATA DIMENSI SUMBERDAYA}

Pelaksanaan wajib belajar 9 tahun yang merupakan kebijakan yang ditetapkan oleh pemerintah sangat tergantung dengan sumberdaya. Kaitannya dengan sumberdaya yang terdapat di Dinas Pendidikan Kota Ternate menurut informan penelitian yakni sekolah dan UPTD sebagai berikut:

\section{A. STAF}

Melaksanakan tugas tugas-tugas memerlukan sumber daya manusia yang memadai. Kesiapan dalam pengelolaan administrasi, pelatihan, dan pemberdayaan dilingkungan Dinas Pendidikan Nasional Kota Ternate dirasa sudah mencukupi oleh informan. Sementara itu, untuk kualifikasi pendidikan strata 2 (S2) yang berada di Dinas Pendidikan Nasional Kota Ternate tidak dilihat sebagai sebuah ukuran tentang kondisi pendidikan Kota Ternate oleh informan. Perspektif informan terkait sumber daya manusia hanya sebatas pada bagaimana kebijakan tersebut berjalan. Tidak dilihat bagaimana inovasi dengan adanya sumber daya manusia yang didorong agar lebih berkualitas. Dukungan Sumber daya manusia yang baik akan memberikan dorongan ke arah perubahan yang diinginkan di segala sektor. Proses yang diinginkan tersebut perlu mendapat perhatian dari pemerintah Kota Ternate. Permasalahan pendidikan merupakan salah satunya yang menjadi prioritas pemerintah Kota Ternate. Hal ini dikarenakan untuk menghadapi kemajuan dan perubahan dunia saat ini membutuhkan sumber daya manusia dan merancang pembangunan selanjutnya dengan kualitas dan inovasi.

B. INFORMASI

Di samping dukungan sumber daya manusia, informasi juga 
mengupayakan agar kebijakan tersebut dapat menyebar kepada pelaksana kebijakan dan masyarakat. Informasi diperlukan agar pelaksana kebijakan dapat merespon kebijakan dengan baik dan ketaatan pelaksana kebijakan dalam menjalankan tugas sebagaimana mestinya.

\section{WEWENANG}

Tanpa wewenang yang cukup maka sekolah-sekolah akan menemui kendala terkait dengan berjalannya wajib belajar 9 tahun di Kota Ternate. Pelimpahan sebagian kewenangan dari Dinas Pendidikan Nasional Kota Ternate kepada sekolah-sekolah dimaksudkan agar sekolah dapat menjalankan peran menciptakan sumber daya manusia yang diinginkan.

\section{FASILITAS}

Dukungan fasilitas terhadap kelancaran kaitannya dengan wajib belajar di Kota Ternate, dari sejumlah informan menjawab perlu mendapat perhatian dari pemerintah. Informan penelitian menyatakan kebutuhan sarana prasarana pendukung baik bangunan, pasokal listrik di daerah terpencil seperti Pulau Moti, dan tenaga pendidik masih belum maksimal. Ada pun informan yang menyatakan sudah cukup dengan fasilitas yang dimiliki sekolah. Alasannya jumlah siswa yang banyak sehingga dan Bantuan Operasional Sekolah (BOS) juga bisa dioptimalkan.

\section{ANALISIS DATA DIMENSI DISPOSISI}

Pengelolaan kebijakan wajib belajar 9 tahun merupakan sesuatu yang sangat di nanti oleh berbagai pihak. Terlaksananya kebijakan tersebut merupakan respon pemerintah terhadap kemajuan pendidikan di Indonesia tanpa terkecuali. Hanya saja permasalahan bermunculan di daerah-daerah yang mengalami kendala. Buruknya fasilitas pendidikan, akses sekolah di daerah terpencil, permasalahan 
kurangnya tenaga pendidik, kemiskinan, dan kebijakan pemerintah daerah dalam upaya perbaikan mutu pendidikan merupakan beberapa fenomena yang belum bisa diatasi.

\section{A. PEMAHAMAN PELAKSANA}

Pendapat-pendapat yang telah disampaikan oleh para informan mengenai pemahaman mereka tentang wajib belajar 9 tahun telah mereka pahami. Konteks pemahaman informan penelitian ini berkisar pada sosialisasi, pendataan, dan pengawasan. Bentuk tindakkan yang dilakukan informan, dinyatakan di dalam PP 47 tahun 2008 yang terdapat pada pasal 5, pasal 9 ayat 2, 3, dan 4 . Selain itu pada pasal 12 ayat 1, 2, dan 3 terkait langsung dengan penjaminan wajib belajar.

\section{B. INSENTIF BAGI PELAKSANA}

Ketersediaan insentif bagi pelaksana kebijakan wajib belajar 9 tahun diperlukan untuk kelancaran pelaksanaan kebijakan di lapangan. Anggaran yang diberikan disesuaikan dengan tugas yang mereka jalankan. Dari keterangan-keterangan yang diberikan kepada peneliti oleh informan, bahwa dukungan sumber daya manusia terkait dengan tenaga pendidik Pulau Moti yang mempergunakan guru honorer, mengakibatkan keuangan sekolah menjadi terbebani dari kebijakan sekolah untuk mempergunakan tenaga honorer. Selain itu jarak yang harus ditempuh oleh pengawas UPTD Pulau Ternate dari satu sekolah dengan sekolah yang lain memerlukan biaya besar. Sementara tugas mereka jalankan setiap hari untuk melakukan pendampingan di sekolah-sekolah.

\section{LOYALITAS}

Bentuk loyalitas pelaksana kebijakan wajib belajar 9 tahun di Kota Ternate belum memperlihatkan bentuk yang ideal untuk diterapkan. Masih ada pelaksana kebijakan yang tidak melakukan aktifitas ditempatnya. Selain itu, sekolah yang berada di wilayah 
terpencil masih merasakan kekurangan diantaranya bangunan perpustakaan yang rusak dan tidak layak huni, kekurangan guru, 1 bangunan dipergunakan bergantian pada setiap minggu oleh 2 sekolah untuk kelas pagi dan siang. Masalah lainnya adalah daya tampung sekolah yang tidak memadai sehingga dibuat 2 rombongan belajar pagi dan siang hari. Dari hasil wawancara dan temuan yang ada menunjukkan bahwa loyalitas pelaksana kebijakan di 3 UPTD dan 8 sekolah telah menjalankan apa yang menjadi kewajiban mereka. Hanya saja pada sikap pelaksana di tingkat elit dalam hal ini Dinas Pendidikan Nasional Kota Ternate belum memberikan respon positif terkait dengan dukungan dan loyalitas sebagaimana yang diharapkan.

\section{ANALISIS DATA DIMENSI STRUKTUR BIROKRASI}

Struktur birokrasi sebagai bagian untuk mempermudah dan menetapkan pembagian tugas, antara satu bagian dengan yang lain. Tantangan yang dihadapi oleh lembaga yang begitu kompleks perlu rancangan mengenai tata kelola organisasi yang baik. Kemampuan sumber daya manusia, komunikasi, budaya, dan profesionalitas pelaksana dibutuhkan tidak hanya memberikan gambaran tetapi konsistensi dalam menjalankan kebijakan.

\section{A. STANDART OPERATING PROCEDURES (SOP)}

Prosedur kerja standar telah dibuat oleh Dinas Pendidikan Kota Ternate untuk merancang kesinambungan organisasi. Pengelolaan yang dilakukan harus melihat kebutuhan dari organisasi tersebut. Hambatan-hambatan yang terjadi dalam pelaksanaan kebijakan perlu evaluasi sehingga dapat dijadikan acuan kebijakan. Pelaksana kebijakan yang berada di Dinas Pendidikan Nasional Kota Ternate telah membuat SOP untuk memperbaiki kinerja. Dari aspek pelayanan, pendirian sekolah, sertifikasi guru dan sebagainya. Hanya saja SOP yang dibuat tidak disosialisasikan kepada pelaksana 
kebijakan yang berada di UPTD.

\section{B. FRAGMENTASI}

Pelaksanaan sebuah kebijakan yang memiliki hubungan langsung sering menjumpai tekanan-tekanan yang berakibat arah kebijakan berubah. Tekanan-tekanan tersebut memberikan dampak yang tidak diinginkan. Kendala tersebut perlu ditekan agar pelaksana kebijakan dapat menjalankan tugas dengan sebaik-baiknya. Bentuk tekanan dari luar struktur sebagai bentuk intervensi untuk melemahkan kebijakan tersebut. Tekanan yang membuat sekolah untuk mengubah arah kebijakan dari sejumlah informan tidak merasakan adanya tekanan, sehingga kewenangan yang diberikan terhadap sekolah tetap dijalankan sebagaimana mestinya. Kebijakan wajib belajar 9 tahun yang berada di Kota Ternate pada aspek fragmentasi tidak mengganggu kinerja pelaksana yaitu sekolah dan UPTD. Hasil penelitian ini berdasarkan 4 indikator yaitu komunikasi, sumberdaya, disposisi, dan struktur birokrasi dapat ditarik kesimpulan bahwa, PP 47 tahun 2008 tentang wajib belajar masih ada permasalahan pada sikap pelaksana kebijakan di wilayah Dinas Pendidikan Nasional Kota Ternate. Dengan dukungan data dokumentasi dan wawancara dengan informan penelitian menunjukkan pelaksana kebijakan di Dinas Pendidikan tidak sensitif dengan laporan-laporan yang diberikan sekolah terkait dengan kendala banyaknya tenaga honorer dan infrastruktur (perpustakaan). Selain itu, rombongan belajar yang mana tidak sesuai dengan kapasitas ruangan dan 2 sekolah bergantian pagi dan siang untuk memakai 1 bangunan sekolah.

\section{KESIMPULAN}

Hasil penelitian ini menemukan berbagai masalah yang beragam terkait dengan wajib belajar 9 tahun di Kota Ternate. Berdasarkan analisis mengenai kebijakan tersebut diatas maka dapat disimpulkan 
sebagai berikut:

1. Implementasi kebijakan wajib belajar 9 tahun dalam meningkatkan mutu pendidikan pada SDN dan SMPN di Kota Ternate belum optimal. Hal dikarenakan masih ada sekolah yang memiliki tenaga honorer yang banyak di SMPN 12 sehingga menjadi beban pembiayaan sekolah. Kemudian sarana dan prasarana sekolah belum memadai seperti 1 bangunan sekolah dipakai bergantian oleh 2 sekolah secara bergantian. Selain itu, bangunan perpustakaan yang terkena abrasi tidak dipakai karena belum diperbaiki. Inilah kondisi yang terjadi di beberapa sekolah yang menjadi objek penelitian ini.

2. Faktor-faktor yang mempengaruhi implementasi kebijakan wajib belajar 9 tahun di SDN dan SMPN di Kota Ternate adalah faktor disposisi, di ikuti faktor komunikasi, faktor sumberdaya dan faktor struktur birokrasi.

3. Faktor disposisi adalah paling menentukan implementasi kebijakan wajib belajar 9 tahun. Hal ini didasarkan pada permasalahan yang berada di sekolah telah dikomunikasikan pihak sekolah kepada pelaksana kebijakan di Dinas Pendidikan Nasional Kota Ternate tetapi belum mendapat respon. Sehingga apa yang telah direncanakan oleh Dinas Pendidikan berjalan ditempat.

Adapun saran untuk perbaikan kedepannya antara lain:

1. Perlu pembenahan terkait dengan infrastruktur dan tenaga pendidik di daerah terpencil dengan memberikan dukungan yang dibutuhkan sekolah.

2. Dinas Pendidikan Nasional Kota Ternate harus lebih rensponsif terhadap bentuk laporan yang diberikan.

3. Memperbaiki kinerja pelaksana yang belum maksimal menjalankan kebijakan wajib belajar 9 tahun.

4. Menempatkan tenaga pendidik yang kompeten di daerah 
terpencil. Hal ini berguna untuk meningkatkan daya saing peserta didik.

\section{DAFTAR PUSTAKA}

Abdul Fahab, Solichin., Analisis Kebijakan Dari Formulasi ke Penyusunan Modelmodel Implementasi Kebijakan Publik, Cetakan ke-2, Jakarta: PT Bumi Aksara, 2014.

Adawiyah, Robiatul dan Karim, H, "Implementasi Bantuan Operasional Sekolah (BOS) dalam Penyelenggaraan Pendidikan Gratis", (2011).

Amal, Adnan M., "Kepulauan Rempah-Rempah, Perjalanan Sejarag Maluku Utara 1250 - 1950, Edisi Kedua, cetakan ke-1, Jakarta: Kepustakaan Populer Gramedia Sama dengan JK School of Government Universitas Muhammadiyah Yogyakarta 2013.

Djojonegoro, Wardiman., Kebijakan Wajib Belajar 9 Tahun, LP3ES Majalah Kajian Ekonomi dan Sosial Nomor 5 Tahun XXIII Mei 1994.

Dwiningrum, Siti Irene Astuti., Desentralisasi dan Partisipasi Masayarakat dalam Pendidikan, cetakan ke-1, Yogyakarta: Pustaka Pelajar, 2011.

Gunawan Arya. H., Kebijakan-Kebijakan Pendidikan, cetakan ke-2, Jakarta: PT. Rineka Cipta, 1995.

Held, David, Demokrasi dan Tatanan Global, Dari Negara Modern Hingga Pemerintahan Kosmopolitan, cetakan ke-l, Yogyakarta: Pustaka Pelajar, 2004.

Maleong, Lexy J., Metodologi Penelitian Kualitatif, Cetakan ke-1, Bandung: PT Remaja Rosdakarya Offset, 2014.

Malik, Hermen, Fajar Kebangkitan Pendidikan Daerah Tertinggal, Cetakan ke- 1, Jakarta: LP3ES, 2013.

\section{JURNAL}

Budiharjo, Markus, et. Al, Implementasi Kebijakan Wajib Belajar 9 Tahun pada Sekolah-Sekolah Swasta (Studi Kasus di Sekolah-Sekolah Khatolik dan Muhammadiyah di Provinsi DIY dan Jawa Tengah), Proposal Penelitian, Fakultas Keguruan dan Ilmu Pendidikan Universitas Sanata Dharma Kerja

Ilyas, Taufiq Rahman, et, al, "Evaluasi Implementasi Program Bantuan Operasional Sekolah (Studi di SDN Bulusari Tarokan Kabupaten Kediri)", Jurnal Administrasi Publik, Nomor 7, Volume 1, hal. 1331-1339. 2013.

Masrukhi, Muhammad, "Partisipasi Masayarakat dalam Pengambilan Kebijakan Publik Bidang Pendidikan di Kota Surabaya", Jurnal Penelitian dan Evaluasi Pendidikan, Nomor 2, hal. 269-284, Tahun XII, 2008.

Nugroho, Riant, Public Policy, edisi ke-4 revisi, Jakarta: Gramedia, 2012. 
Nugroho, Rosihan Widi, et, al, "Implementasi Kebijakan Penggunaan Dana Bantuan Operasional Sekolah di Kota Semarang (Studi Kasus di Sekolah Menengah Pertama Negeri Semarang Selatan Tahun 2011)", Jurnal Nomor 1, Volume 2, 2013.

Nurdyana, et, al. " Pendidikan dan Kemiskinan Di Maluku Utara." 2012.

Parlindungan, et, al. "Impementasi Kebijakan Program Wajib Belajar Pendidikan

Dasar 9 Tahun Pada Pondok Pesantren Salawiyah di Kabupaten Kubu Raya". Jurnal Tesis PMIS Universitas Tanjung Pura, 2013.

Rahmat, Pupu Saeful, "Penelitian Kualitatif", Jurnal Equlibrium Nomor 9, Volume 05, hal 1-8, Januari-Juli 2009.

Salim, Agus., Teori dan Paradigma Penelitian Sosial, Buku Sumber Untuk Penelitian Kualitatif, edisi ke-4, cetakan ke-I, Yogyakarta: Tiara Wacana, 2006.

Sigoyono, Metode Penelitian Kombinasi (Mixed Methods), Cetakan ke-3, Bandung: Alfabeta, 2011.

Suranto, Kualitas Pelayanan Publik Telaah Faktor-faktor Determinan, cetakan ke-1, Yogyakarta:CV Visitama, 2013.

Tilaar, H.A.R, dan Nugroho Riant, Kebijakan Pendidikan Pengantar Untuk Memahami Kebijakan Pendidikan dan kebijakan Pendidikan Sebagai Kebijakan Publik, Cetakan ke - 3, Yogyakarta, 2012.

Wibowo, Pranomo Anung., Mahalnya Demokrasi Memudarnya Ideologi, Potret Komunikasi Politik Legislator Konstituen, Cetakan ke- 1, Jakarta: 2013. 